V.A. Grishin, Mathematics Physics PhD, Assoc. Prof., Odessa I.I. Mechnikov National University, V.A. Grishina, Mathematics Physics PhD, Assoc. Prof., Odessa National Polytechnic University, V.V. Reut, Mathematics Physics PhD, Assoc. Prof., Odessa I.I. Mechnikov National University

\title{
STRESS STATE OF THE BOX SHELL UNDER THE INDENTATION OF TWO INCLUSIONS
}

Introduction. Thin-walled structures are widely used in various fields in modern technologies of mechanical engineering, construction, aviation industry, shipbuilding, rocket engineering, oil, gas and other industries. Variety of forms of such structures, various loading conditions and pinning, presence of defects and inhomogeneities lead to wide range of different formulations of the problems of research on strength characteristics of such structures and methods used for this purpose.

Literature review. The characteristic feature of this type of problems is the difficulty of solving them both using analytical methods and numerical calculations on computer. Therefore, the study of this problem is still relevant. Intensive search continues both in theoretical study of the problem and in development of approximate numerical calculation methods. Study on the convergence of the numerical method is of great importance in the development of numerical methods for solving practical problems using the finite element method. It is very important to have an opportunity to explore the validity of numerical method by comparing it with analytical solution of such a problem.

Among the first studies in this area there are works of V.Z. Vlasov, G.Yu. Dzhanelidze, Ya.G. Panovko, S.N. Kan, E. Reissner. Tasks for composite shell structures in accordance with their actual interaction were solved by V.I. Mossakovskiy and his students using method of homogeneous solutions. Application of direction with functions having non-integrable singularity developed by G.Ya. Popov [1] and his students allowed to solve many problems for mechanics of deformable solids including problems for shell structures.

The authors of this article developed a method that allowed to solve effectively the problem of stress state of lamellar shells [2]. Application of this method with the method of regularization of divergent integrals [1] allowed to solve a number of problems for the lamellar shells with defects, such as [3..6].

Aim of the Research is to solve the problem of plane-bending stress state of box shell with rectangular profile and infinite length under the indentation of two symmetrically arranged thin rigid inclusions.

Main Body. Let's consider the problem of stress state of box shell with infinite length and rectangular profile under the indentation of two thin rigid inclusions symmetrically located on the opposite faces (Fig. 1).

The load acting on shell will be assumed symmetrical about the plane of symmetry of the shell.

Let's use the method of calculating the box shells [2], retaining the notations. The problem reduces to finding the solution of differential equa-

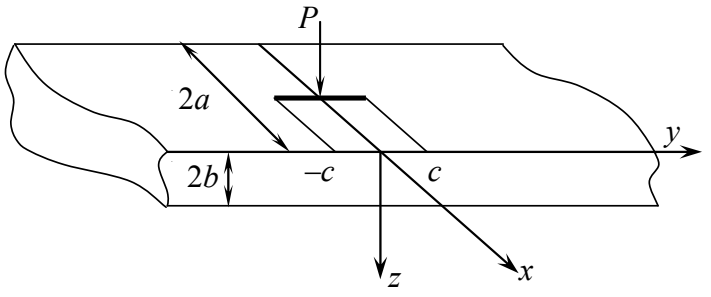

Fig. 1. Loading scheme of rectangular profile shell with rigid inclusion: $a, b$ - the geometric dimensions of rectangular cross section of the shell; $2 c$ - the length of inclusion; $P$ - the concentrated force tions system 


$$
\begin{aligned}
& D \Delta^{2} w(x, y)=Z(x, y), \quad-a<x<b, x \neq 0,|y|<l \\
& \Delta^{2} \sigma_{x}(x, y)=\Phi(x, y), \quad \\
& \Phi(x, y)=\partial / \partial x\left[\Delta+(1+v) \partial^{2} / \partial y^{2}\right] X+\partial / \partial y\left[\Delta-(1+v) \partial^{2} / \partial y^{2}\right] Y,
\end{aligned}
$$

satisfying the conditions at the edge of the shell at

$$
\begin{aligned}
& \langle v\rangle=\left\langle\tau_{x y}\right\rangle=\left\langle\varphi_{x}\right\rangle=\left\langle M_{x}\right\rangle=0, \\
& \langle u\rangle=-\left(w_{+}+w_{-}\right) ; \quad\langle w\rangle=u_{+}+u_{-}, \\
& \left\langle\sigma_{x}\right\rangle=-h^{-1}\left[\left(V_{x}\right)_{+}+\left(V_{y}\right)_{-}\right], \\
& \left\langle V_{x}\right\rangle=h\left[\left(\sigma_{x}\right)_{+}+\left(\sigma_{y}\right)_{-}\right] ;
\end{aligned}
$$

satisfying the symmetry conditions

$$
\begin{aligned}
& V_{y}=\varphi_{y}=v=\tau_{x y}=0, \quad-a<x<b ; \quad y=0, \\
& V_{x}=\varphi_{x}=u=\tau_{x y}=0, \quad x=-a, b ; \quad|y|>c ;
\end{aligned}
$$

conditions for the inclusion

$$
u(-a, y)=\varphi_{x}(-a, y)=0 ; w(-a, y)=\delta \quad|y|<c
$$

under the conditions of equilibrium for the inclusion

$$
\int_{-c}^{c} V_{x}(-a, y) d y=-P / 2
$$

where $P$ is the load acting on the inclusion;

$\delta$ is the upsetting of the inclusion;

$u, v, w$ are the movements along the axis $x, y, z$;

$\varphi, M, V, \sigma, \tau$ are the angle of rotation, the bending moment, the generalized lateral force, the normal and tangential stresses respectively;

$X(x, y), Y(x, y), Z(x, y)$ are the loads acting on the shell along the axis $x, y, z$ respectively;

functions with lower index \pm denote the limit values of the corresponding functions on the edge, and the values in angle brackets are their jumps: $f_{ \pm}=f( \pm 0) ;\langle f\rangle=f_{-}-f_{+}$.

Because of symmetry the equilibrium condition for the tangential stresses are performed automatically, and the displacement of the inclusion $\delta$ is unknown beforehand.

Let $\chi(y)$ and $\mu(y)$ be the unknown lateral force and tangential stresses on the inclusion

$$
\chi(y)=V_{x}(-a, y) ; \mu(y)=\tau_{x y}(-a, y),
$$

that differ from zero by (1) on inclusion $|y|<c$ only.

Let's apply the Fourier transform to the elastic bending and flat unknown variables and denote

$$
\left(\begin{array}{ccccc}
w_{\alpha} & \varphi_{\alpha} & M_{\alpha} & u_{\alpha} & \chi_{\alpha} \\
\sigma_{x \alpha} & V_{\alpha} & Z_{\alpha} & X_{\alpha} & \mu_{\alpha}
\end{array}\right)=\int_{-\infty}^{+\infty}\left(\begin{array}{ccccc}
w & \varphi_{x} & M_{x} & u & \chi(y) \\
\sigma_{x} & V_{x} & Z & X & \mu(y)
\end{array}\right) e^{i \alpha y} d y .
$$

If transformants are indexed with \pm ( + for plate - for bending problems) in the notations of [1] and the transformant of Laplace operator is denoted by $L$

$$
L f=\left[d^{2} / d x^{2}-\alpha^{2}\right] f,
$$

then we come to the problem in transformants for the system of differential equations

$$
\begin{aligned}
& L^{2} f_{\alpha}^{ \pm}=q_{\alpha}^{ \pm}(x)+P_{\alpha}^{ \pm}(x), \quad-a<x<b, x \neq 0, \\
& q_{\alpha}^{+}(x)=R_{3}^{+} X_{\alpha}+\alpha R_{2}^{+} Y_{\alpha}, \quad q_{\alpha}^{-}(x)=D^{-1} Z_{\alpha}, \\
& P_{\alpha}^{+}(x)=-\mu_{\alpha} \alpha R_{2}^{+} \delta(x+a), \quad P_{\alpha}^{-}(x)=-\chi_{\alpha} D^{-1} \delta(x+a)
\end{aligned}
$$

with boundary conditions for $x=-a, b$ 


$$
R_{3}^{ \pm} f_{\alpha}^{ \pm}=R_{1}^{ \pm} f_{\alpha}^{ \pm}=0
$$

and conditions at the edge of the shell

$$
\begin{array}{ll}
S_{j}^{ \pm} f_{\alpha}^{ \pm}=0, \quad j=1,2, & \\
S_{3}^{+} f_{\alpha}^{+}=\alpha^{4} E\left[H_{0}^{-} f_{\alpha}^{-}\right], & H_{3}^{+} f_{\alpha}^{+}=\alpha^{4} E\left[S_{0}^{-} f_{\alpha}^{-}\right], \\
S_{0}^{+} f_{\alpha}^{+}=D h^{-1}\left[H_{3}^{-} f_{\alpha}^{-}\right], & H_{0}^{+} f_{\alpha}^{+}=-D h^{-1}\left[S_{3}^{-} f_{\alpha}^{-}\right] .
\end{array}
$$

The following notation of differential operators and functionals $R_{j}^{ \pm}, S_{j}^{ \pm}, H_{j}^{ \pm}, T_{j}^{ \pm}$are used [2]:

$$
\begin{gathered}
R_{k}^{ \pm} f=\frac{\partial^{k} f}{\partial x^{k}}, k=0,1, R_{2}^{ \pm} f=\left[L+(1 \pm v) \alpha^{2}\right] f, \\
R_{3}^{ \pm} f=\frac{\partial}{\partial x}\left[L-(1 \pm v) \alpha^{2}\right] f, \quad L f=\frac{d^{2} f}{d x^{2}}-\alpha^{2} f, \\
S f=\left(T^{-}-T^{+}\right) f, H f=\left(T^{-}+T^{+}\right) f, \quad T^{ \pm} f=f( \pm 0), \\
S_{k}^{ \pm} f=S\left[R_{k}^{ \pm} f\right], H_{k}^{ \pm} f=H\left[R_{k}^{ \pm} f\right], T_{k}^{ \pm} f=T\left[R_{k}^{ \pm} f\right] .
\end{gathered}
$$

The solution of (3) ... (5) will be found as the solutions of two following tasks.

The first task is to find the solution of the problem for the shell without the inclusion under the action of arbitrary load, but without taking into account the load on inclusion. In system (3) this problem corresponds to the right side of $q_{\alpha}^{ \pm}(x)$. Its solution is found in [2], let's mark it by index $q$ and assume that it is known.

The second task is to find the solutions for the shell with the inclusion under the load on the inclusion. Its solution is also built on the scheme presented in [2] and the presence of inclusion is replaced by the action of unknown load $\chi(y)$ and $\mu(y)$ which action in system (3) is accounted in form of components

$$
\begin{aligned}
& f_{p}^{-}(x)=\int_{-a}^{b} G_{\alpha}(x, t) P_{\alpha}^{-} d t=-\chi_{\alpha} D^{-1} G_{\alpha}(x,-a), \\
& f_{p}^{+}(x)=\int_{-a}^{b} G_{\alpha}(x, t) P_{\alpha}^{+} d t=-\mu_{\alpha} \alpha \widetilde{R}_{2}^{+} G_{\alpha}(x,-a) .
\end{aligned}
$$

The solution to this problem let's mark by index $p$. Here the wave over the operator $R_{2}$ means that it applies to the second variable of the Green function $G_{\alpha}(x, \xi)$, and the Green function is constructed for the boundary value problem

$$
L^{2} u(x)=0, \quad x \in(a, b) ; u^{\prime}=u^{\prime \prime \prime}=0, \quad x=-a, b .
$$

Solution of the problem in transformants $\mu_{\alpha}(y)$ and $\chi_{\alpha}(y)$ is obtained by solving the algebraic system of fourth order

$$
A F=\mu_{\alpha} H_{\mu}+\chi_{\alpha} H_{\chi}
$$

with coefficients of matrix $A$

$$
A=\left\|\begin{array}{cccc}
h D^{-1} & 0 & -C_{33}^{-} & C_{30}^{-} \\
0 & \left(\alpha^{4} E\right)^{-1} & -C_{03}^{-} & C_{00}^{-} \\
-C_{33}^{+} & C_{30}^{+} & -\alpha^{4} E & 0 \\
-C_{03}^{+} & C_{00}^{+} & 0 & -D h^{-1}
\end{array}\right\|,
$$

where coefficients of matrix $A$ and vectors $H_{\mu}$ and $H_{\chi}$ are obtained as a result of use of functional $H_{j}^{ \pm}, T_{j}^{ \pm} \quad(j=0,3)$ to the Green function $G_{\alpha}(x, \xi)$ 


$$
\begin{gathered}
C_{i j}^{ \pm}=H_{i}^{ \pm} T_{j}^{ \pm}\left[G_{\alpha}\right], \\
H_{\mu}=\left[0,0, \alpha H_{3}^{+} R_{2}^{+} G_{\alpha}(x,-a),-\alpha H_{3}^{+} R_{2}^{+} G_{\alpha}(x,-a)\right]^{T}, \\
H_{\chi}=\left[D^{-1} H_{3}^{-} G_{\alpha}(x,-a), D^{-1} H_{o}^{-} G_{\alpha}(x,-a), 0,0\right]^{T} .
\end{gathered}
$$

To determine the functions $\chi(y)$ and $\mu(y)$ let's find the inverse values of transformants $w_{\alpha}(x)$ and $v_{\alpha}(x)$ and use the condition (1). After the separation of weakly converging parts of cores we obtain the system of integral equations of the form

$$
\int_{-1}^{1}\left[\begin{array}{cc}
(y-\eta)^{2} \ln |y-\eta| & 0 \\
0 & -\ln |y-\eta|
\end{array}\right]\left[\begin{array}{l}
\chi(\eta) \\
\mu(\eta)
\end{array}\right] d \eta+\int_{-1}^{1}\left[\begin{array}{c}
K_{11} K_{12} \\
K_{21} K_{22}
\end{array}\right]\left[\begin{array}{l}
\chi(\eta) \\
\mu(\eta)
\end{array}\right] d \eta=\left[\begin{array}{l}
\delta_{\chi}(y) \\
\delta_{\mu}(y)
\end{array}\right],
$$

where $K_{i j}(y, \eta)$ are infinitely differentiable functions;

$\delta_{\chi}(y), \delta_{\mu}(y)$ are upsettings of inclusions caused by loads $\chi, \mu$ respectively.

The first of integral equations (6) has no solution in class of integrable functions and its solution must be sought in the space of functions with non-integrable singularities of the form $\left(1-y^{2}\right)^{-3 / 2}$ using the apparatus of the regularization of divergent integrals [7].

To solve the system (6) let's use the method of orthogonal polynomials and seek $\mu(y)$ as series of expansion in terms of Chebyshev polynomials of the first kind $T_{2 m+1}(s)$ and $\chi(y)$ as series of expansion in terms of polynomials of special kind $\pi_{k}(y)$ obtained as a modification of Jacobi polynomials [8]:

$$
\begin{aligned}
& \mu(s)=\delta\left(1-s^{2}\right)^{-\frac{1}{2}} \sum_{m=0}^{\infty} \mu_{2 m+1} T_{2 m+1}(s), \\
& \chi(s)=\delta \sum_{m=0}^{\infty} \chi_{2 m} \pi_{2 m}(s) .
\end{aligned}
$$

Considering the spectral ratios [8]

$$
\begin{aligned}
& \int_{-1}^{1}(t-\tau)^{2} \ln |t-\tau| \pi_{2 n}(\tau) d \tau=2 \pi P_{2 n}(t), \quad(-1 \leq t \leq 1), \\
& \int_{-1}^{1} \frac{T_{2 l+1}(s)}{\sqrt{1-s^{2}}} \ln \frac{1}{|y-s|} d s=\pi(2 l+1)^{-1} T_{2 l+1}(y), \quad(-1 \leq t \leq 1),
\end{aligned}
$$

we obtain an infinite system of linear algebraic equations for the coefficients of the expansion $\left\{\chi_{2 k}, \mu_{2 k+1}\right\}$

$$
\left(\begin{array}{l}
\chi_{2 l} \\
\mu_{2 l+1}
\end{array}\right)+\sum_{k=0}^{\infty}\left(\begin{array}{l}
A_{11}^{k, l} A_{12}^{k, l} \\
A_{21}^{k, l} A_{22}^{k, l}
\end{array}\right)\left(\begin{array}{l}
\chi_{2 k} \\
\mu_{2 k+1}
\end{array}\right)=\delta\left(\begin{array}{l}
c_{l} \\
0
\end{array}\right), \quad l=\overline{0, \infty},
$$

where coefficients of the system $A_{i j}^{k, l}(i, j=1,2)$ and the right sides $c_{l}$ are expressed in terms of rapidly converging integrals, which include Bessel and Gamma functions for different $k, l=\overline{0, \infty}$.

Results. Solution of the system when substituted in the equilibrium condition (2), taking into account the linearity of dependence of upsetting on the load, allows to define the amount of upsetting $\delta$. The values of the elastic unknowns can be determined by using the solution of the problem in the transformants (3) ... (5) and the convolution theorem.

To determine the upsetting $\delta$ there were carried out the numerical calculations in case when the shell is loaded by forces $P$ applied to the means of inclusions. Values of the dimensionless analogue of upsetting $\delta^{0}$ related to the physical value were calculated by the ratio $\delta=\delta^{0} \cdot P / E h$. Calculations were performed for a number of values $a / b$ and $c / a$ when $v=0,3, h / a=0,01$. And the system of 
linear algebraic equations was solved by the method of reduction while maintaining five members of expansion providing an accuracy of at least three significant digits. Fig. 2 shows the dimensionless values of upsetting $\delta^{0}$ for the four cross-section ratios $a / b=\{0,5 ; 1 ; 2 ; 4\}$, depending on the inclusion length $c$ related to one of geometric sectional dimension $a$.

Conclusions. Note that when $c \rightarrow 0$ the values of inclusions upsetting match with known results on the deflection values under the point of application of concentrated force of shell without inclusions loaded with two symmetrically arranged forces.

In conclusion, note that proposed method [2] allowed to replace the consideration of stress state of the spatial angled design by consideration of stress state of the band with a linear defect that allowed to halve the number of differential equations needed to be solved and

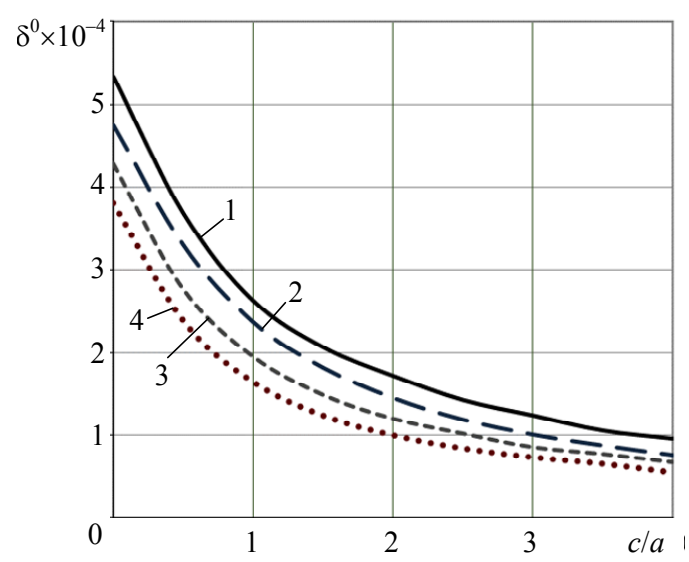

Fig. 2. The value of inclusion upsetting $\delta^{0}$ depending on the length of inclusion c/a for various ratios of geometrical dimensions $a / b$ : $1-a / b=0,5 ; 2-a / b=1 ; 3-a / b=2 ; 4-a / b=4$ to simplify the conditions for coupling.

As it is known, the exact solutions of such problems have not been obtained by other authors and numerical or experimental results are not shown. However, it was carried out the verification of used method by considering the modeling problems. In particular, it has been successfully considered the problem with inclusions infinite by length on the opposite faces loaded with infinite distributed load. This problem has a trivial solution and is solved by methods of strength of materials. The comparison showed the advantages of the proposed method.

\section{Література}

1. Попов, Г.Я. Избранные труды / Г.Я. Попов. - Одесса: Изд.-полиграф. дом ВМВ, 2007. — . T. 1. $-2007 .-438 \mathrm{c}$.

2. Гришин, В.А. Расчет коробчатых оболочек прямоугольного сечения / В.А. Гришин, В.В. Реут, Г.Я. Попов // Прикладная математика и механика. - 1990. - Т. 54, Вып. 4. - С. $605-612$.

3. Grishin, V. The stress state of box shell weakened by cracks / V. Grishin, V. Grishina // International Conference on Modern Analysis and Applications (MAA 2007) dedicated to the centenary of Mark Krein: Book of abstracts, Odessa, Ukraine, April 9-14, 2007. — Kyiv, 2007. — PP. 54 - 55.

4. Reut, V. The problem on the stress state of a cube boxed shell / V. Reut, E. Reut // International Conference on Modern Analysis and Applications (MAA 2007) dedicated to the centenary of Mark Krein: Book of abstracts, Odessa, Ukraine, April 9-14, 2007. - Kyiv, 2007. — PP. 120 - 121.

5. Grishin, V.A. Box-like shells with longitudinal cracks / V.A. Grishin, V.V. Reut, E.V. Reut // Modern Analysis and Applications: The Mark Krein Centenary Conference, Odessa, Ukraine, April 9-14, 2007. Basel: Birkhäuser Verlag, 2009. — Vol. 2: Differential Operators and Mechanics. — PP. 357 - 364.

6. Исследование интенсивности напряжения пластинчатой конструкции с трещинами под действием изгибающей нагрузки / В.А. Гришин, В.А. Гришина, В.В. Реут, Е.В. Реут // Методи розв'язування прикладних задач механіки деформованого твердого тіла. - 2012. - Вип. 13. C. $106-113$.

7. Онищук, О.В. Об особенностях контактных усилий при изгибе пластин с тонкими включениями / О.В. Онищук, Г.Я. Попов, П.Г. Фаршайт // Прикладная математика и механика. - 1986. - Т. 50, Вып. 2. - С. 293 - 302.

8. Попов, Г.Я. Концентрация упругих напряжений возле штампов, разрезов, тонких включений и подкреплений / Г.Я. Попов. - М.: Наука, 1982. — 342 с. 


\section{References}

1. Popov, G.Ya. (2007). Selected Works. Vol. 1. Odessa: VMV.

2. Grishin, V.A., Popov, G.Ya. and Reut, V.V. (1990). Analysis of box-like shells of rectangular crosssection. Journal of Applied Mathematics and Mechanics, 54(4), 501-507.

3. Grishin, V. and Grishina, V. (2007). The stress state of box shell weakened by cracks. In Book of abstracts of International Conference on Modern Analysis and Applications (MAA 2007) dedicated to the centenary of Mark Krein (pp. 54-55). Kyiv: Institute of mathematics, National Acad. of Sci. of Ukraine.

4. Reut, V. and Reut, E. (2007). The problem on the stress state of a cube boxed shell. In Book of abstracts of International Conference on Modern Analysis and Applications (MAA 2007) dedicated to the centenary of Mark Krein (pp. 120-121). Kyiv: Institute of mathematics, National Acad. of Sci. of Ukraine.

5. Grishin, V.A., Reut, V.V. and Reut, E.V. (2009). Box-like shells with longitudinal cracks. In V. Adamyan, Y.M. Berezansky, I. Gohberg, M.L. Gorbachuk, V. Gorbachuk, A.N. Kochubei, H. Langer, G. Popov (Eds.), Modern Analysis and Applications: The Mark Krein Centenary Conference. Vol. 2, Differential Operators and Mechanics (pp. 357-364). Basel: Birkhäuser Verlag.

6. Grishin, V.A., Grishina, V.A., Reut, V.V. and Reut, E.V. (2012). Study of stress intensity in plate with cracks under bending load. Methods of Solving Applied Problems in Solid Mechanics, 13, 106-113.

7. Onishchuk, O.V., Popov, G.Ya. and Farshait, P.G. (1986). On the singularities of contact forces in the bending of plates with fine inclusions. Journal of Applied Mathematics and Mechanics, 50(2), 219-226.

8. Popov, G.Ya. (1982). Concentration of Elastic Stresses near Stamps, Cuts, Thin Inclusions and Reinforcements. Moscow: Nauka.

\section{АНОТАЦІЯ / АННОТАЦИЯ / ABSTRACT}

B.О. Гришин, В.О. Гришина, В.В. Реут. Напружений стан коробчатої оболонки при вдавленні в неї двох включень. Тонкостінні конструкції різного профілю широко використовуються в будівництві, авіаційній промисловості, суднобудуванні, ракетобудуванні, нафтовій, газовій промисловості. Різноманітність форм таких конструкцій, умов навантаження, наявності дефектів і неоднорідностей приводить до широкого спектра постановок задач міцності об'єктів і методів їх розв'язування. Характерна особливість задач подібного типу є складність їх аналітичного і чисельного розв'язування. Оцінка збіжності чисельного методу розв'язання вимагає можливості порівняння отриманих чисельних результатів з результатами аналітичного рішення відповідної задачі.

Робота присвячена розв'язанню задачі про напружений стан коробчатої оболонки прямокутного профілю і нескінченної довжини при вдавлюванні в оболонку двох симетрично розташованих жорстких тонких включень. Задача зводиться до системи інтегральних рівнянь. Розв'язування шукається у просторі функцій, що мають неінтегровні особливості із застосуванням апарату регуляризації розбіжних інтегралів. Нескінченна система лінійних алгебраїчних рівнянь, що одержується, розв'язується методом редукції. Чисельно отримані значення осадок включень залежно від довжини включень і співвідношень геометричних розмірів поперечного перерізу оболонки.

Ключові слова: напружений стан оболонки, неінтегровні особливості, регуляризація розбіжних інтегралів, метод ортогональних многочленів, осадки включень.

B.А. Гришин, В.А. Гришина, В.В. Реут. Напряженное состояние коробчатой оболочки при вдавливании в нее двух включений. Тонкостенные конструкции различного профиля широко используются в строительстве, авиационной промышленности, судостроении, ракетостроении, нефтяной, газовой промышленности. Разнообразие форм таких конструкций, условий нагружения, наличия дефектов и неоднородностей приводит к широкому спектру постановок прочностных задач и методов их решения. Характерной особенностью задач подобного типа является сложность их аналитического и численного решения. Оценка сходимости численного метода решения требует возможности сравнения полученных численных результатов с результатами аналитического решения соответствующей задачи.

Работа посвящена решению задачи о напряженном состоянии коробчатой оболочки прямоугольного профиля и бесконечной длины при вдавливании в нее двух симметрично расположенных жестких тонких включений. Задача сводится к системе интегральных уравнений. Решение ищется в пространстве функций, имеющих не интегрируемые особенности с применением аппарата регуляризации расходящихся интегралов. Получаемая бесконечная система линейных алгебраических уравнений решается методом редукции. Численно получены значения осадок включений в зависимости от длины включений и соотношений геометрических размеров поперечного сечения оболочки.

Ключевые слова: напряженное состояние оболочки, неинтегрируемые особенности, регуляризация расходящихся интегралов, метод ортогональных многочленов, осадки включений.

V.A. Grishin, V.A. Grishina, V.V. Reut. Stress state of the box shell under the indentation of two inclusions. Thinwalled structures are widely used in various fields in modern technologies of mechanical engineering, construction, aviation industry, shipbuilding, rocket engineering, oil, gas and other industries. Variety of forms of such structures, various loading conditions and pinning, presence of defects and inhomogeneities lead to wide range of different formulations of the problems of research on strength characteristics of such structures and methods used for this purpose. The characteristic feature of this 
type of problems is the difficulty of their analytical or numerical solving. Assessment of convergence of numerical method solution requires the ability to compare the numerical results with analytical solution results of the corresponding problem.

The research is devoted to solving the problem of stress state of box-shell with rectangular profile and infinite length under the indentation of two symmetrically arranged thin rigid inclusions. The problem is reduced to a system of integral equations. The solution is sought in the space of functions that have nonintegrable singularities using the apparatus of the regularization of divergent integrals. Obtained infinite system of linear algebraic equations is solved by the method of reduction. There are obtained the numerical values of the upsettings of inclusions depending on inclusions length and ratios of geometric dimensions of the cross-section of the shell.

Keywords: stress state of the shell, nonintegrable singularities, regularization of divergent integrals, method of orthogonal polynomials, upsetting of inclusion.

Received January 28, 2015 